\title{
Kinerja Keuangan dan Nilai Perusahaan: Analisis Data Panel pada Jakarta Islamic Index
}

\author{
Yudhistira Ardana \\ Sistem Informasi, STMIK Pringsewu \\ ardanayudhistira@gmail.com
}

\begin{abstract}
Abstrak
Penelitian ini bertujuan untuk mengetahui pengaruh kinerja keuangan terhadap nilai perusahaan. Pengambilan data dilakukan pada tahun 2012 sampai dengan tahun 2017. Penelitian ini mencoba untuk menganalisis pengaruh kinerja keuangan yang diproksikan dengan 3 (tiga) variabel bebas, yaitu rasio likuiditas (quick ratio) sebagai $X 1$, rasio profitabilitas (ROA) sebagai X2, dan rasio solvabilitas (Debt to Total Assets Ratio) sebagai X3 terhadap variabel dependen/terikat yang berupa nilai perusahaan (Price Book Value) sebagai Y pada perusahaaan yang terdaftar di Jakarta Islamic Index (JII). Teknik analisis data yang digunakan dalam penelitian ini adalah menggunakan regresi data panel. Hasil penelitian ini yaitu variabel independen rasio profitabilitas dan solvabilitas berpengaruh secara positif dan signifikan terhadap variabel dependen berupa nilai perusahaan yang diukur dengan Price to Book Value (PBV). Sedangkan variabel independen rasio likuiditas yang diukur dengan quick ratio tidak memiliki pengaruh terhadap nilai perusahaan.
\end{abstract}

Kata kunci : Kinerja keuangan, Profitabilitas, Likuiditas, Solvabilitas 
Yudhistira Ardana_Kinerja Keuangan Dan Nilai Perusahaan: Analisis Data Panel Pada Jakarta Islamic Index

\section{A. Latar Belakang}

Banyak pengusaha yang mendirikan perusahaannya mempunyai tujuan ingin perusahaannya maju dan memaksimumkan nilai perusahaan serta mendapatkan keuntungan semaksimal mungkin. Selain itu, perusahaan juga memiliki tujuan utama dari didirikannya perusahaan tersebut, yaitu untuk memaksimumkan kesejahteraan atau kekayaan para pemegang saham, yang mana dapat diartikan dengan memaksimumkan harga saham guna meningkatkan nilai perusahaan tersebut (Febrianti, 2012). Perusahaan merupakan penyatuan antara berbagai kepentingan pemegang saham (shareholders) dan manajemen yang bertujuan memaksimalkan nilai perusahaan. Itu berarti memaksimalkan nilai kekayaan para pemegang saham adalah tujuan akhir dari suatu perusahaan. Peningkatan nilai perusahaan mengindikasikan meningkatnya kekayaan pemegang saham (Ali dan Maryam, 2015).

Menurut Putu, dkk (2014), nilai perusahaan adalah persepsi investor terhadap perusahaan yang sering dikaitkan dengan harga saham. Bagi perusahaan publik nilai perusahaan yang biasanya dicerminkan oleh harga pasar (market price) saham perusahaan tersebut. Para investor membeli saham biasa karena mereka mengharapkan suatu imbalan (return) atas investasi mereka. Imbalan ini dapat berupa apresiasi harga saham dan deviden kepada para pemegang saham (Simamora, 2010). Nilai perusahaan dapat dilihat dari harga penjualan sahamnya, karena para investor dapat menilai perusahaan tersebut memiliki keuntungan yang tinggi atau tidak dari tingginya harga saham. Karena dengan meningkatnya nilai perusahaan, maka meningkat pula kesejahteraan para pemegang saham perusahaan tersebut (Aditya, 2015).

Pada dasarnya harga saham dipengaruhi oleh profitabilitas di masa yang akan datang dan resiko yang ditanggung oleh pemodal. Harga saham yang tinggi membuat nilai perusahaan juga tinggi. Nilai perusahaan yang tinggi akan membuat pasar tidak hanya percaya pada kinerja perusahaan 
Yudhistira Ardana_Kinerja Keuangan Dan Nilai Perusahaan: Analisis Data Panel Pada Jakarta Islamic Index

saat ini namun juga pada prospek masa depan perusahaan (Ali dan Maryam, 2015). Untuk menilai suatu perusahaan dari harga pasar saham, biasanya digunakan pengukuran kinerja perusahaan. Semakin baik kinerja perusahaan, maka semakin tinggi return yang akan diperoleh oleh investor (Meythi, 2013). Bagi sebuah perusahaan, menjaga dan meningkatkan kinerja perusahaan adalah suatu keharusan agar saham perusahaan tersebut tetap eksis dan tetap diminati oleh para investor (Mahendra, dkk, 2012).

Untuk mengukur kinerja keuangan suatu perusahaan dapat dilakukan dengan menganalisis laporan keuangan pada perusahaan tersebut, salah satu caranya adalah dengan melakukan analisis rasio keuangan perusahaan, karena analisis laporan keuangan yang banyak digunakan adalah rasio keuangan (Santoso, 2016). Rasio keuangan berguna dalam mengidentifikasi variabel keuangan utama dan hubungan antara variabel dengan maksud memberi makna pada berbagai hubungan sambil memastikan kekuatan dan kelemahan dari sebuah perusahaan. Dalam penelitian ini kinerja suatu perusahaan diukur dengan rasio - rasio keuangan. Rasio - rasio keuangan tersebut adalah likuiditas yang diukur dengan Quick Ratio, solvabilitas yang diukur dengan Debt to Total Asset serta profitabilitas yang diukur dengan Return on Assets. Sedangkan nilai perusahaan diukur dengan Price Book Value.

Adapun hubungan antara ketiga rasio di atas sebagai alat pengukur kinerja perusahaan dengan nilai perusahaan, menurut penelitian yang dilakukan oleh Aditya (2015) dengan obyek perusahaan manufaktur yang terdaftar di Bursa Efek Indonesia periode 2011-2013 menemukan hasil yang menyatakan bahwa likuiditas berpengaruh terhadap nilai perusahaan. Sedangkan hasil penelitian yang dilakukan oleh Febrianti (2012) pada perusahaan industri pertambangan menunjukkan bahwa likuiditas mempunyai pengaruh yang positif terhadap nilai perusahaan, namun tidak signifikan. 
Yudhistira Ardana_Kinerja Keuangan Dan Nilai Perusahaan: Analisis Data Panel Pada Jakarta Islamic Index

Selanjutnya, hubungan antara rasio profitabilitas dengan nilai perusahaan, menurut penelitian yang dilakukan oleh Sianturi (2015) menyatakan profitabilitas berpengaruh positif terhadap nilai perusahaan dikarenakan kontribusi peningkatan laba dapat memberikan indikasi bagi pemegang saham bahwa tingkat pengembalian investasi semakin tinggi dan gambaran prospek perusahaan yang semakin baik karena adanya potensi peningkatan keuntungan atas jumlah modal yang disediakan oleh para pemegang saham.

Kemudian hubungan antara rasio solvabilitas dengan nilai perusahaan, menurut penelitian yang dilakukan oleh Santoso (2016) menunjukkan hasil yang menyatakan bahwa rasio solvabilitas berpengaruh secara signifikan terhadap nilai perusahaan. Hal ini diperkuat oleh penelitian yang dilakukan oleh Susilaningrum (2016) yang menyatakan bahwa terdapat pengaruh rasio solvabilitas terhadap nilai perusahaan pada industri sektor pertambangan pada periode 2012-2014. Untuk melakukan investasi, khususnya untuk kegiatan jual-beli saham, biasanya para investor melakukan transaksinya di pasar modal. Pasar modal merupakan pasar keuangan untuk dana jangka panjang. Instrumen yang yang digunakan dalam pasar modal pada umumnya antara lain saham, obligasi, dan tim right (Pakpahan, 2003). Sedangkan menurut Martono dan Harjito (2001) Pasar modal (capital market) adalah suatu pasar di mana dana-dana jangka panjang baik hutang maupun modal sendiri diperdagangkan. Dana jangka panjang yang diperdagangkan tersebut diwujudkan dalam surat-surat berharga. Menerbitkan saham merupakan salah satu pilihan perusahaan ketika memutuskan untuk pendanaan perusahaan. Di sisi lain, saham merupakan instrumen investasi yang paling banyak dipilih oleh para investor karena saham mampu memberikan tingkat keuntungan yang menarik (Nurlita, 2014).

Banyak penelitian yang telah dilakukan terhadap pengaruh faktor fundamental dan teknikal terhadap harga saham, akan tetapi masih jarang dilakukannya pada saham syariah. Jakarta Islamic Index (JII) sebagai salah 
Yudhistira Ardana_Kinerja Keuangan Dan Nilai Perusahaan: Analisis Data Panel Pada Jakarta Islamic Index

satu indeks harga saham syariah memiliki kinerja yang baik dibandingkan dengan indeks-indeks saham lainnya, bahkan Indeks harga saham syariah, Jakarta Islamic Index (JII) menguat $0,16 \%$ ke 682,73 pada perdagangan akhir sesi I Kamis (27/11/2014). Sepanjang hari indeks bergerak pada kisaran 681,62-684,62. Penguatan ini sejalan dengan pergerakan indeks harga saham gabungan (IHSG). Dari 30 saham yang diperdagangkan, sebanyak 18 saham menguat, 7 saham melemah, dan 5 saham stagnan. CPIN tercatat paling menguat, yakni sebesar 3,4\%. Untuk itu diperlukannya penelitian lebih lanjut pada Jakarta Islamic Index (JII) sebagai salah satu indeks saham yang memiliki kinerja yang baik di Indonesia.

Berdasarkan latar belakang yang diungkapkan di atas, maka peneliti tertarik untuk melakukan penelitian dengan judul Kinerja Keuangan dan Nilai Perusahaan : Analisis Data Panel pada Jakarta Islamic Index.

\section{B. Metode Penelitian}

Penelitian ini menggunakan pendekatan kuantitatif. Menurut eksplanasinya penelitian ini termasuk penelitian asosatif. Penelitian dilakukan dengan pengambilan data sekunder dan hasil publikasi laporan keuangan perusahaan yang terdaftar pada Jakarta Islamic Index melalui situs www.idx.co.id. Pengambilan data dilakukan pada tahun 2012 sampai dengan tahun 2017. Penelitian ini mencoba untuk menganalisis pengaruh kinerja keuangan yang diproksikan dengan 3 (tiga) variabel bebas, yaitu rasio likuiditas (quick ratio) sebagai $\mathrm{X} 1$, rasio profitabilitas (ROA) sebagai $\mathrm{X} 2$, dan rasio solvabilitas (Debt to Tatal Assets Ratio) sebagai X3 terhadap variabel dependen/terikat yang berupa nilai perusahaan (Price Book Value) sebagai $Y$ pada perusahaaan yang terdaftar di Jakarta Islamic Index (JII). Teknik analisis data yang digunakan dalam penelitian ini adalah menggunakan regresi data panel. Model dasar yang digunakan pada penelitian ini adalah sebagai berikut:

NILAlit $=\mathbf{a}+$ B1LKDit + B2PROFITit + B3SOLit + eit 
Dalam regresi data panel terdapat empat model yang dapat digunakan. Model tersebut antara lain: model OLS pooled, model fixed effects least square dummy variabel (LSDV), model fixed effects within-group dan model random effect (Gujarati: 2013). Pemilihan model yang akan dipakai, diseleksi dengan uji spesifikasi model.

\section{Hasil Penelitian dan Pembahasan}

\section{Uji Chow}

Pertama-tama data panel diesmitasi menggunakan efek spesifikasi fixed. Uji yang dilakukan yaitu uji Chow. Uji ini bertujuan untuk mengetahui apakah sebaiknya model menggunaka fixed effect atau common effect.

$$
\begin{array}{ll}
\mathrm{H}_{\mathrm{O}} & \text { : Common Effect } \\
\mathrm{H}_{\mathrm{a}} & \text { : Fixed Effect }
\end{array}
$$

Apabila hasil probabilitas chi-square kurang dari 5\%, maka ditolak. Sehingga, Model menggunakan fixed effect. Hasil dari estimasi menggunakan efek spesifikasi fixed adalah sebagai berikut :

Tabel 1 Hasil tes Rebundant Fixed Effect-Likelihood Ratio

Redundant Fixed Effects Tests

Pool: PANEL

Test cross-section fixed effects

\begin{tabular}{lrrr}
\hline \hline Effects Test & Statistic & d.f. & Prob. \\
\hline \hline Cross-section F & 1.415999 & $(13,67)$ & 0.0154 \\
Cross-section Chi-square & 20.390754 & 13 & 0.0059 \\
\hline \hline
\end{tabular}


Yudhistira Ardana_Kinerja Keuangan Dan Nilai Perusahaan: Analisis Data Panel Pada Jakarta Islamic Index

Berdasarkan hasil di atas, diketahui probabilitas Chi-square sebesar 0,0059 sehingga menyebabkan $\mathrm{H}_{\circ}$ ditolak. Maka model fixed adalah model yang sebaiknya digunakan.

\section{Correlated Random Effect-Hausmann Test}

Uji ini bertujuan untuk mengetahui apakah model random effect lebih baik digunakan dari fixed effect.

$$
\begin{array}{ll}
\mathrm{H}_{\circ} & : \text { Random Effect } \\
\mathrm{H}_{\mathrm{a}} & \text { : Fixed Effect }
\end{array}
$$

Apabila hasil probabilitas chi-square lebih dari 5\%, maka sebaiknya model menggunakan random effect. Hasil dari estimasi menggunakan efek spesifikasi random adalah sebagai berikut :

\section{Tabel 2 Hasil uji Hausman}

Correlated Random Effects - Hausman Test

Pool: PANEL

Test cross-section random effects

\begin{tabular}{lcrc}
\hline \hline Test Summary & $\begin{array}{r}\text { Chi-Sq. } \\
\text { Statistic }\end{array}$ & $\begin{array}{r}\text { Chi-Sq. } \\
\text { d.f. }\end{array}$ & Prob. \\
\hline \hline Cross-section random & 7.711683 & 3 & 0.0052 \\
\hline \hline
\end{tabular}

Hasil probabilitas chi-square sebesar 0,0000. Sehingga dapat disimpulkan bahwa model sebaiknya menggunakan fixed effect.

\section{Analisis Data Panel}

Dari uji spesifikasi di atas, maka model sebaiknya menggunakan estimasi dengan efek tetap (fixed effect). Pada pengujian sebelumnya, model 
Yudhistira Ardana_Kinerja Keuangan Dan Nilai Perusahaan: Analisis Data Panel Pada Jakarta Islamic Index

telah lolos dari uji asumsi klasik, sehingga hasil estimasi konsisten dan tidak bias. Hasil estimasi model regresi data panel adalah sebagai berikut:

Tabel 3 Regresi Data Panel Fixed Effect

Dependent Variable: NILAI?

Method: Pooled Least Squares

Date: 07/16/18 Time: 16:10

Sample: 20122017

Included observations: 6

Cross-sections included: 14

Total pool (balanced) observations: 84

\begin{tabular}{|c|c|c|c|c|}
\hline \multicolumn{5}{|c|}{ Coefficien } \\
\hline Variable & $\mathrm{t}$ & Std. Error & t-Statistic & Prob. \\
\hline & -17.39429 & 3.002678 & -5.792927 & 0.0000 \\
\hline LKDT? & 0.077917 & 0.765207 & 0.101824 & 0.9192 \\
\hline PROFIT? & 101.9374 & 7.846655 & 12.99119 & 0.0000 \\
\hline SOL? & 26.52716 & 5.513245 & 4.811532 & 0.0000 \\
\hline & \multicolumn{3}{|c|}{ Mean dependent } & 5.67940 \\
\hline R-squared & \multicolumn{3}{|c|}{$0.802849 \mathrm{var}$} & \\
\hline Adjusted R-squared & 0.755768 & \multicolumn{2}{|c|}{ S.D. dependent var } & \\
\hline S.E. of regression & 6.059980 & \multicolumn{2}{|c|}{ Akaike info criterion } & \\
\hline Sum squared resid & 2460.465 & \multicolumn{2}{|c|}{$\begin{array}{l}\text { Schwarz criterion } \\
\text { Hannan-Quinn }\end{array}$} & $\begin{array}{r}9 \\
6.81768\end{array}$ \\
\hline Log likelihood & \multicolumn{3}{|c|}{-261.0370 criter. } & \\
\hline F-statistic & 17.05253 & \multirow{2}{*}{\multicolumn{2}{|c|}{ Durbin-Watson stat }} & 1 \\
\hline Prob(F-statistic) & 0.000000 & & & \\
\hline
\end{tabular}

Dari hasil di atas dapat disimpulkan bahwa pada regresi model fixed effect variabel profitabilitas dan solvabilitas berpengaruh terhadap nilai perusahaan yang terdaftar pada Jakarta Islamic Index yang mana secara berturut-turut hasil probabilitas sebesar 0,0000 dan 0,000. Sedangkan variabel likuiditas tidak berpengaruh terhadap nilai perusahaan yang terdaftar pada Jakarta Islamic Index dengan nilai probabilitas sebesar 0,9192 serta 
Yudhistira Ardana_Kinerja Keuangan Dan Nilai Perusahaan: Analisis Data Panel Pada Jakarta Islamic Index

nilai ketidakseimbangan sebesar $75,57 \%$. Secara simultan antara kinerja keuangan yang diproksikan oleh variabel likuiditas, profitabilitas dan solvabilitas berpengaruh siginifikan terhadap nilai perusahaan yang terdaftar dalam Jakarta Islamic Index (JII). Hal ini dibuktikan dengan nilai probabilitas regresi model fixed effect yaitu 0,000000 lebih kecil dari taraf signifikansi $5 \%$ dan nilai $F$ statistic yang lebih besar dari $F$ tabelnya. Hasil penelitian ini sesuai dengan temuan penelitian yang dilakukan oleh Sianturi (2015) dan Santoso (2016) yang mengemukakan bahwa rasio profitabilitas dan rasio solvabilitas berpengaruh secara positif dan signifikan terhadap nilai perusahaan. Sedangkan penelitian yang dilakukan oleh Febrianti (2012) menemukan hasil bahwa rasio likuiditas berpengaruh terhadap nilai perusahaan namun tidak signifikan.

Likuiditas tidak berpengaruh terhadap nilai perusahaan. Hasil penelitian ini sesuai dengan penelitian yang dilakukan oleh Mahendra (2011) dan Febrianti (2012). Kondisi likuiditas yang tidak berpengaruh terhadap nilai perusahaan dapat diinterpretasikan bahwa nilai aktiva lancar dengan perbandingan hutang jangka pendek tidak memberikan pengaruh positif dalam meningkatkan nilai perusahaan, walaupun rasio yang digunakan untuk mengukur likuiditas juga menunjukkan tingkat kemanan kreditor jangka. Penemuan dalam penelitian ini tidak sesuai dengan temuan Aditya (2015), Marsha dan Murtaqi (2017), French, dkk (2012) dan Susilaningrum (2016). Jika perusahaan memiliki kemampuan yang bagus dalam memenuhi kewajiban jangka pendeknya dengan menggunakan aktiva lancar maka perusahaan dapat dikatakan likuid, sehingga para investor tidak perlu khawatir dalam menginvestasikan dananya, jika suatu saat terjadi hal yang tidak diinginkan.

Profitabilitas memiliki pengaruh yang positif dan signifikan terhadap nilai perusahaan. Hasil temuan ini sesuai dengan temuan penelitian yang dilakukan oleh Sianturi (2015) dan Mahendra, dkk (2012), Sucuahi dan Cambarihan (2016). Hal ini berarti bahwa ketika suatu perusahaan 
Yudhistira Ardana_Kinerja Keuangan Dan Nilai Perusahaan: Analisis Data Panel Pada Jakarta Islamic Index

meningkatkan kinerja keuangannya, hal tersebut dapat menciptakan nilai perusahaan. Hasil penelitian tersebut menandakan bahwa memiliki nilai perusahaan yang baik akan menarik lebih banyak investor dan kepentingan pihak lain untuk ikut serta dan berperan bagi perusahaan. Sehingga, merupakan hal yang penting untuk menciptakan dan menentukan nilai perusahaan guna terwujudnya investasi yang handal (Sucuahi dan Cambarihan, 2016). Selaini itu masih terdapat penelitian yang mendukung hasil dari penelitian ini yaitu penelitian yang dilakukan oleh Wardoyo dan Ardimas (2014), Pertiwi dan Pratama (2012), Sudarsono (2015), Putri (2015). Hal ini menunjukkan bahwa semakin naik kinerja keuangan maka kemungkinan akan terjadi peningkatan pada nilai perusahaan, dan sebaliknya apabila kinerja keuangan semakin menurun maka nilai perusahaan akan mengalami penurunan. Oleh karena itu, return on assets (ROA) merupakan salah satu faktor yang berpengaruh terhadap nilai perusahaan (Pertiwi dan Pratama, 2012). Apabila kinerja keuangan perusahaan yang dicerminkan oleh return on assets tinggi, maka nilai perusahaan juga akan semakin meningkat karena nilai perusahaan ditentukan oleh earning power dari aset perusahaan. Semakin tinggi earning power, maka semakin efisien perputaran aset dan semakin tinggi profit margin yang diperoleh perusahaan.

Hasil penelitian ini menemukan bahwa rasio solvabilitas memiliki pengaruh positif dan signifikan terhadap nilai perusahaan. Hasil temuan ini sesuai dengan penelitian yang telah dilakukan oleh Santoso (2016), Susilaningrum (2016), Aditya (2015) dan Febrianti (2012). Hasil peneliti lain berlawanan dengan hasil penelitian yang sebelumnya, penelitian yang dilakukan oleh Sianturi (2015) dan Stiyarini (2016) menemukan hasil bahwa solvabilitas berpengaruh negatif terhadap nilai perusahaan dikarenakan perusahaan yang memiliki tingkat hutang yang tinggi akan menyebabkan beban bunga yang dibayarkan perusahaan juga tinggi, hal ini akan mengurangi kemampuan perusahaan dalam menghasilkan laba dan hal ini 
mempengaruhi keputusan investor dalam menginvestasikan dananya atau membeli saham suatu perusahaan. Perusahaan yang memiliki rasio solvabilitas yang tinggi, akan berdampak timbulnya resiko kerugian lebih besar, namun juga ada kesempatan untukmendapat laba yang lebih besar. Investor menganggap perusahaan yang mempunyai banyak hutang akan mempunyai kesempatan dalam menggunakan modalnya untuk ekspansi atau pengembangan, dengan harapan semakin berkembangnya perusahaan maka keuntungan bagi perusahaan dan investor juga akan semakin naik sehingga investor tertarik untuk membeli saham perusahaan tersebut.

\section{E. Kesimpulan}

Berdasarkan dari data-data yang telah dikumpulkan dan dilakukan pengujian terhadap data-data tersebut yang berupa 14 sampel perusahaan yang terdaftar pada Jakarta Islamic Index periode 2012-2017 dengan menggunakan regresi data panel, maka dapat diambil kesimpulan bahwa model yang cocok adalah menggunakan fixed effect variabel independen rasio profitabilitas dan solvabilitas berpengaruh secara positif dan signifikan terhadap variabel dependen berupa nilai perusahaan yang diukur dengan Price to Book Value (PBV). Sedangkan variabel independen rasiolikuiditas yang diukur dengan quick ratio tidak memiliki pengaruh terhadap nilai perusahaan.

\section{Daftar Pustaka}

Aditya, M.A.E. 2015. Pengaruh Rasio Keuangan Terhadap Nilai Perusahaan Manufaktur yang Terdaftar di Bursa Efek Indonesia. Artikel IImiah, diajukan untuk memenuhi salah satu syarat penyelesaian program pendidikan sarjana jurusan Akuntansi. Sekolah Tinggi IImu Ekonomi PERBANAS, Surabaya.

Ali, M dan M. Maryam. 2015. An Analysis of the Influence of Ownership Structure, Investment, Liquidity and Risk to Firm Value: Evidence 
Yudhistira Ardana_Kinerja Keuangan Dan Nilai Perusahaan: Analisis Data Panel Pada Jakarta Islamic Index

from Indonesia. American Journal of Economics and Business Administration 2015, 7 (4): 166.176.

Febrianti, M. 2012. Faktor-faktor yang Mempengaruhi Nilai Perusahaan Pada Industri Pertambangan di Bursa Efek Indonesia. Jurnal Bisnis dan Akuntansi. Vol. 14, no.2.

French, J.J., W. Li, C.C. Chen,. The relationship between liquidity, corporate governance, and firm valuation: Evidence from Russia. Elsevier, Emerging Markets Review 13 (2012) 465-477.

Gujarati Damodar \& Dawn Porter. 2013. Dasar-dasar Ekonometrika Buku 2. Jakarta : Salemba Empat.

Mahendra, A., L.G.S. Artini, A.A.G. Suarjaya,. 2012. Pengaruh Kinerja Keuangan Terhadap Nilai Perusahaan Pada Perusahaan Manufaktur di Bursa Efek Indonesia. Jurnal Manajemen. Strategi Bisnis, dan Kewirausahaan. Vol. 6, No. 2.

Mahendra, Alfredo. 2011. Pengaruh Kinerja Keuangan Terhadap Nilai Perusahaan (Kebijakan Dividen Sebagai Variabel Moderating) Pada Perushaan Manufaktur di Bursa Efek Indonesia. Tesis Megister (Tidak dipublikasikan), Bali: Universitas Udayana.

Marsha, N. Dan I. Murtaqi. 2017. The Effect of Financial Ratios on Firm Value in The Food and Beverage Sector of The IDX. Journal of Business and Management. Vol 6, No. 2, 2017.

Martono dan D.A. Harjito. 2001. Manajemen Keuangan. Penerbit Ekonisia, Yogyakarta.

Meythi. 2013. Rasio Keuangan Terbaik Untuk Memprediksi Nilai Perusahaan. Jurnal Keuangan dan Perbankan. Vol. 17, No. 2.

Nurlita, A. 2014. Investasi di Pasar Modal Syariah dalam Kajian Islam. Jurnal Penelitian Sosial Keagamaan, Vol. 17, No. 1. Januari-Juni 2014.

Pakpahan, K. 2003. Strategi Investasi di Pasar Modal. Journal The Winners, Vol. 4. No. 2, September 2003 
Yudhistira Ardana_Kinerja Keuangan Dan Nilai Perusahaan: Analisis Data Panel Pada Jakarta Islamic Index

Pertiwi, T.K. dan F.M.I. Pratama. 2012. Pengaruh Kinerja Keuangan, Good Corporate Governance Terhadap Nilai Perusahaan Food And Beverage. Jurnal Manajemen Dan Kewirausahaan, Vol.14, No. 2, September 2012: 118-127

Putri, A.O. 2015. Pengaruh Kinerja Keuangan Terhadap Nilai Perusahaan Dengan Pengungkapan CSR Sebagai Variabel Pemoderasi. Jurnal IImu dan Riset Manajemen, Volume 4, Nomor 4, April 2015.

Putu, N.N.G.M, Moeljadi, A.D. Djumahir. 2014. Factors Affecting Firms Value of Indonesia Public Manufacturing Firms. International Journal of Business and Management Invention, ISSN (Online): 2319 - 8028, ISSN (Print): 2319 - 801X, www.ijbmi.org Volume 3 Issue 2ll February. 2014\|l PP.35-44.

Santoso, B.H. 2016. Pengaruh Kinerja Keuangan Terhadap Nilai Perusahaan Pada Perusahaan Jasa Telekomunikasi. Jurnal IImu dan Riset Manajemen: Volume 5, Nomor 2, Februari 2016.

Sianturi, M. W. E. 2015. Pengaruh Kinerja Keuangan Terhadap Nilai Perusahaan Manufaktur Sektor Industri Barang Konsumsi di BEI. EJournal Ilmu Administrasi Bisnis, 2015, 3 (2).

Simamora, Henry. 2010. Keputusan Akuntansi Basis Pengambilan Bisnis. Jakarta : Salemba Empat

Skripsi Sarjana (Tidak dipublikasikan), Semarang: Fakultas Ekonomi Universitas Negeri Semarang.

Stiyarini. 2016. Pengaruh Kinerja Keuangan Terhadap Nilai Perusahaan Pada Perusahaan Jasa Telekomunikasi. Jurnal IImu dan Riset Manajemen: Volume 5, Nomor 2, Februari 2016.

Sucuahi, W. dan J.M. Cambarihan. 2016. Influence of Profitability to the Firm Value of Diversified Companies in the Philippines. Accounting and Finance Research. Vol. 5, No. 2, 2016. 
Sudarsono, M.A. 2015. Pengaruh Struktur Modal, Kebijakan Dividen, Keputusan Investasi, dan Profitabilitas tarhadap Nilai Perusahaan (Studi Pada Perusahaan yang Efeknya Terdaftar di Daftar Efek Syariah Tahun 20112013).

Susilaningrum, C. 2016. Pengaruh Return On Assets, Rasio Likuiditas, dan Rasio Solvabilitas terhadap Nilai Perusahaan dengan Pengungkapan Corporate Social Responsibility (CSR) Sebagai Variabel Moderasi. Jurnal Profita Edisi 8 Tahun 2016.

Wardoyo dan W. Ardimas. 2014. Pengaruh Kinerja Keuangan Dan Corporate Social Responsibility Terhadap Nilai Perusahaan Pada Bank Go Public Yang Terdaftar di BEI. BENEFIT Jurnal Manajemen dan Bisnis, Volume 18, Nomor 1, Juni 2014, hlm. 57 - 66. 